Наносистели, нанолатеріали, нанотехнології Nanosistemi, Nanomateriali, Nanotehnologii 2018, т. 16, № 2, сc. 289-301 (c) 2018 ІМФ (Інститут металофізики ім. Г. В. Курдюмова НАН України) Надруковано в Україні. Фотокопіювання дозволено тільки відповідно до ліцензії

\title{
A Study on 2D 2-Dot 1-Electron QCA Based Full Adder and Ripple Carry Adder Design
}

\author{
Md. Abdullah-Al-Shafi \\ Institute of Information Technology (IIT), \\ University of Dhaka, \\ Dhaka, Bangladesh
}

The restrictions of complementary metal-oxide semiconductor (CMOS) technology proceeded to the breakthroughs of novel technologies. Among the rising technologies in the nanoscale field, quantum-dot cellular automata (QCA) are a significant term. This imminent nanotechnology is composing its aspect due to extreme competence and small area prerequisite and reduces the critical practical boundaries of CMOS. In this study, two-dimensional two-dot one-electron QCA cells, a variation of two-dimensional four-dot two-electron QCA cells, are applied to model a full adder. Later, the proposed adder is utilized to develop a ripple carry adder. Latent energies have been processed to verify and analyze the outlined layout. The concerns associated with power and energy depletion have also been conferred, and it is realized that the volume of power and energy required to drive these designs is incredibly minimal. Lastly, the outlined design has been assessed with the design with fourdot two-electron QCA cells.

Обмеження технології виготовлення комплементарних металооксидних напівпровідникових (КМОП) інтегральних схем передували проривам новітніх технологій. Серед технологій у наномасштабній галузі, що набирають ваги, квантово-точкові клітинні автомати (ККА) є значущим елементом. Ця невідворотня нанотехнологія становить свій аспект через екстремальну компетентність і невеликого обсягу передумову та понижує критичні практичні межі КМОП. У цьому дослідженні для моделювання повного суматора застосовуються двовимірні двоточкові одноелектронні комірки ККА - варіяція двовимірних чотироточкових двоелектронних ККА-комірок. Потім пропонований суматор використовується для створення суматора наскрізного перенесення. Приховані (потенційні) енергії було оброблено для перевірки й аналізи наміченої схеми. Було також обговорено проблеми, пов'язані зі зменшенням потужности й енергії, та встановлено, що обсяг потужности й енергії, необхідний для керування цими схемами, є надзвичайно мінімальним. Нарешті, описану конструкцію було оцінено за допомогою конструкції із чотироточковими двоелект- 
ронними комірками ККА.

Ограничения технологии изготовления комплементарных металлооксидных полупроводниковых (КМОП) интегральных схем предшествовали прорывам новейших технологий. Среди приобретающих вес технологий в наномасштабной области, квантово-точечные клеточные автоматы (ККА) являются значимым элементом. Эта неотвратимая нанотехнология составляет свой аспект из-за экстремальной компетентности и небольшого объёма предпосылки и понижает критические практические границы КМОП. В этом исследовании для моделирования полного сумматора применяются двумерные двухточечные одноэлектронные ячейки ККА - вариация двумерных четырёхточечных двухэлектронных ККА-клеток. Позже предлагаемый сумматор используется для создания сумматора сквозного переноса. Потенциальные (скрытые) энергии были обработаны для проверки и анализа намеченной схемы. Были также обсуждены проблемы, связанные с уменьшением мощности и энергии, и установлено, что объём мощности и энергии, необходимый для управления этими схемами, чрезвычайно минимален. Наконец, описанная конструкция была оценена с помощью конструкции с четырёхточечными двухэлектронными ячейками ККА.

Key words: quantum-dot cellular automata, full adder, ripple carry adder, majority vote, Coulomb's repulsion.

Ключові слова: квантово-точкові клітинні автомати, повний суматор, суматор наскрізного перенесення, мажоритарна схема, Кулонове відштовхування.

Ключевые слова: квантово-точечные клеточные автоматы, полный сумматор, сумматор сквозного переноса, мажоритарная схема, кулоновское отталкивание.

(Received 8 March, 2018; in revised version, 2 May, 2018)

\section{INTRODUCTION}

The usual CMOS archetype has been beneath encounter by the evolving QCA nanoscale technology as respects to power and area obligations are involved. CMOS archetype has attained its ascending limit because of quantum-mechanical properties and additional off-state leakage current is required for proper power utilization. Quantum-dot cellular automata (QCA) is set forth by Lent and Tougaw [1], which appeal to research group for particularly lesser dimensions, better processing speed, extensive duration, and minimal power utilization. Besides, the intrinsic hitches of CMOS model as drawback to the lessening returns in switching operation, off-state leakage, and sustained scaling are overwhelmed by QCA nanotechnology. QCA offers an explanation at nanoscale and proposes a novel technique of computation, modification and information transmission, among the leading six rising technolo- 
gies in imminent computers [2-5]. No power lines require to be directed on the inside, so the key benefit of QCA is if a feedback is passed to a threshold of a QCA clock: it is estimated and result is attained at a different clocking threshold. Besides, it is essential the minimum energy to increase to raise the electrons from their initiate state in QCA system. The QCA scheme does away with off dimensional constraints and reduced switching operation, which are the intrinsic shortcomings of the CMOS schemes. In this study, 2-dimensional 2-dot 1-electron QCA cells are used. 4-dot 2-electron cell has two electrons inside four points, while 2-dot 1-electron cell has simply unique electron inside two dots. The main advantage of 2-dot 1-electron QCA is that the figure of dots and of electrons each cell is half of that in case of 4-dot 2electron QCA. Furthermore, out of the six conceivable formations, just two are acceptable [6]. In addition, as binary communication routes from cell to cell through the inter-cellular interface following the rule of Coulomb, the wiring difficulty is decreased. This study is organized in 7 sections. Section 2 reviews the formations of 2-dimensional 2-dot 1-electron QCA. The full adder and ripple carry adder design is proposed in Section 3. Sections 4 and 5 present the conceivable energy calculations and derivation of inner energy of electron with depleted power study of 2-dot 1-electron QCA design, correspondingly. Subsequently, the total power and energy essential to organize the architecture is discussed in Section 6. Lastly, Section 7 concludes this study.

\section{INTRODUCTION TO 2-DOT 1-ELECTRON QCA}

Separate formations of cells result in several variants of QCA. A fourdot 2-electron cell designed of two electrons and four nanoshape quantum dots has a four-sided outline, while an oblong 2-dot 1-electron cell covers one electron and two dots. In 2-dot 1-electron QCA, the distinct electron is adept of signifying the binary communication through its possession in the quantum dots. The oblong arrangement of 2-dot 1electron QCA permits it to support either horizontally or precipitately, thus directing to separate binary communication representations for separate placements as presented in Fig. 1. The view of the electron inside a cell signifies binary material that occurs from cell to cell utilizing the interface following the Coulomb's theory. The fundamental el-

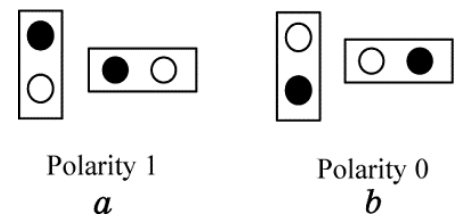

Fig. 1. Structure of QCA cells. 
ements of 2-dot 1-electron QCA are the binary wire, the inverter applying a cell of separate alignments in between two cells of a binary wire, the inverters by revolving at corners, crossing wires, and the majority voter. These structures are presented in Fig. 2, and a convincing explanation is organized in [7].

QCA clocking of 2-dot 1-electron is fairly changed from the CMOS clocking in the perception that CMOS clocking orchestrates the processes, while 2-dot 1-electron clocking not only regulates the way of the signal movement but also provides energy to instable signals so as to they can broadcast over the architecture [8]. So, the QCA clocking supports to realize two essential needs. The clocking scheme of 2-dot 1electron customized of QCA follows equal technique of 4-dot 2-electron QCA. QCA clocking system is quasi-adiabatic. All QCA design comprises four clock regions [9, 10]. Each clocking region of QCA covers four segments, i.e. switch, hold, release, and relax [11, 12]. Primarily, once the possible electron energy is depleted [13] and the electron is not

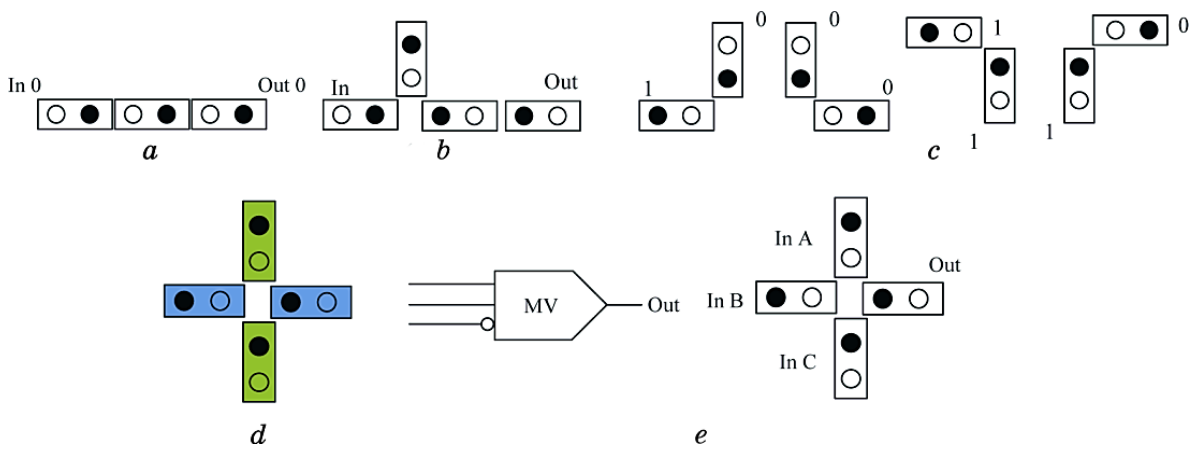

Fig. 2. QCA structure blocks: binary wires of $(a) 90^{\circ}$ and $(b) 45^{\circ} ;(c)$ inverted/non-inverted turnings; $(d)$ planar crossing of wire; $(e)$ majority voter realization.



Fig. 3. Four phase clocking mechanism in QCA. 
adept of channelling between dots, it has a settled polarity.

With the initiating of the switch stage, the conceivable energy of electrons begins to ascent, and, at the edge of this stage, the electron achieves its topmost latent energy. Through the hold stage, the electron preserves its topmost latent energy and converts delocalized dropping its polarity. In the release stage, the conceivable energy of the electron leads to lower, and the cell steadily changes to a certain polarity. In the final phase or relax phase, the electron has lowest energy and, moreover, weak to channel between the quantum dots. Therefore, cell reaches a certain polarity. Every single clock zone is $\pi / 2$ out of stage with the succeeding clock zone as shown in Fig. 3. The clock regions in QCA architecture are epitomized by unique colours, and colour codes used in this work is shown in Fig. 3.

\section{PROPOSED MODELS IN QCA}

$X$ and $Y$, two bits, are added with the third bit of carry-in signal, $C_{\text {in }}$, by a full adder. Figure 4, $a$ presents rational figure and 2-dot 1-electron QCA operation of full adder. The resultant functions of the design are specified by the Eqs. (1) and (2), respectively. In this study, a 4-bit ripple carry adder is proposed and based on full adder presented in Fig. 4. The implemented ripple carry adder is shown in Fig. 5. $X_{i}, Y_{i}$ and $C_{i-1}$ are counted to acquire the sum $S_{i}$ and the carry $C_{i}$. $S_{i}$ and $C_{i}$ signify the resultant 4-bit binary sum and carry, correspondingly. The ultimate carry output is denoted by $C_{\text {out }}$.

$$
\operatorname{Sum}(S)=X \oplus Y \oplus C_{\text {in }},
$$

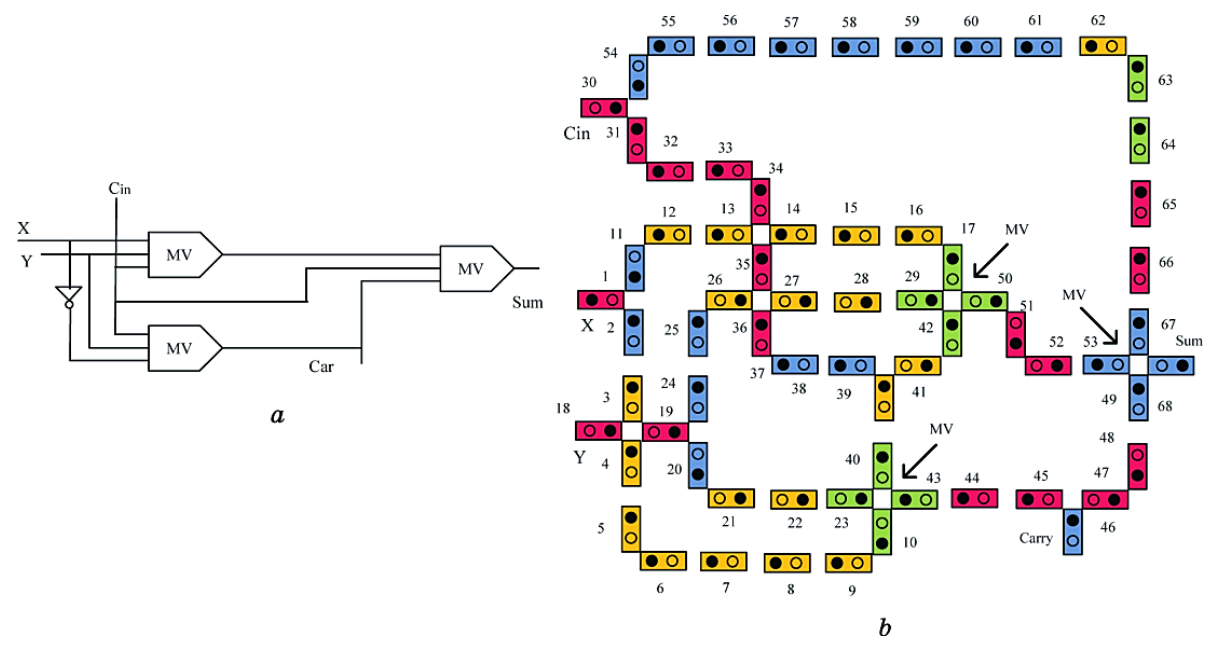

Fig. 4. Proposed full adder: (a) QCA logical presentation; (b) QCA outline. 




Fig. 5. Proposed ripple carry adder.

$$
\operatorname{Carry}\left(C_{\mathrm{in}}\right)=X . Y+X . C_{\mathrm{in}}+Y . C_{\mathrm{in}} .
$$

\section{ANALYSIS OF OUTPUT ENERGY STATUS}

To rationalize the outputs of 2-dot 1-electron QCA designs, some recourse to orthodox mathematical functions are applied. To confirm a circuit, Coulomb's rule is utilized to analyze the potential energy [8]. Let $q_{0}$ and $q_{1}$ be two dot charges divided by a distance $d$. The latent energy between them is

$$
E_{t}=k q_{0} q_{1} / d \text {. }
$$

In Equation (3), $k$ is Boltzmann constant. Thus, 


$$
k q_{0} q_{1}=\mathbf{9} \cdot 10^{9} \cdot(\mathbf{1 . 6})^{2} \cdot 10^{-38} .
$$

Next, latent energy of an electron, in view of the effects of all the adjoining electrons, is

$$
E_{T}=\sum_{t=1}^{n} E_{t}
$$

Meanwhile, an electron can shift in between the dots, and it manages to shift to a status where the conceivable energy is minimal. This possession is applied to form the result. In this work, the conceivable energies for all potential points of an electron inside cells are calculated and then have one minimum potential energy chosen. The potential energies of proposed full adder are presented in Table 1, and afterward, the outcome attains in Table 1 to achieve Table 2 presenting the possible energies for the cells in layout exposed in Fig. 5.

The input signal has to enter the gate concurrently with identical potency; majority voter output is attained at the uniform or succeeding clock phase; these circumstances confirm that a model is perpetual. Fig-

TABLE 1. Output status of 2-dot 1-electron full adder design.

\begin{tabular}{c|c|c|c}
\hline Cell & $\begin{array}{c}\text { Electron } \\
\text { situation }\end{array}$ & $\begin{array}{c}\text { Overall } \\
\text { conceivable energy }\end{array}$ & Remarks \\
\hline $1,18,30$ & - & - & Input cell $X, Y$ and $C_{\text {in }}$, correspondingly \\
$2-11$ & - & - & Cell 1 polarity is attended \\
12 & - & - & Cell 11 is attained inverse polarity \\
$13-17$ & - & - & Cell 1 attains inverse polarity \\
$20-26$ & - & - & Cell 19 attains polarity \\
$28-33$ & - & - & Cell 27 attains polarity \\
$35-38$ & - & - & Cell 34 is attained inverse polarity \\
39 & - & - & Cell 20 is attained inverse polarity \\
$40-42$ & - & - & Cell 39 is attained inverse polarity \\
43 & $x$ & $3.330 \cdot 10^{-20} \mathrm{~J}$ & Electron will latch at site $y$ \\
$44-46$ & - & $0.539 \cdot 10^{-20} \mathrm{~J}$ & because of deficient energy \\
$47-49$ & - & - & Cell 43 attains polarity \\
50 & $x$ & $-6.912 \cdot 10^{-20} \mathrm{~J}$ & Cell 17 is attained inverse polarity \\
$52-54$ & $y$ & $-0.297 \cdot 10^{-20} \mathrm{~J}$ & Electron will latch at site $x$ \\
because of deficient energy \\
$55-61$ & - & - & Cell 50 attains polarity \\
$62-66$ & - & - & Cell 53 is attained inverse polarity \\
67 & $x$ & $5.912 \cdot 10^{-20} \mathrm{~J}$ & Cell 11 is attained inverse polarity \\
Electron will latch at site $y$ \\
\end{tabular}


TABLE 2. Output state of 2-dot 1-electron ripple carry adder design.

\begin{tabular}{cc}
\hline Cell & Remarks \\
\hline 1 & Input cell Cin \\
$2,4,6,9$ & Input cells $X, X_{0}, X_{1}, X_{2}$, correspondingly \\
$3,5,7,10$ & Input cells $Y, Y_{0}, Y_{1}, Y_{2}$, correspondingly \\
$11-25$ & Achieves the polarity of the sum of $X, Y$ and $C_{\text {in }}$ \\
$26-28$ & Achieves the polarity of the carry of $X, Y$ and $C_{\text {in }}$ \\
$29-40$ & Achieves the polarity of the sum of $X_{0}, Y_{0}$ and $C_{0}$ \\
$41-42$ & Achieves the polarity of the carry of $X_{0}, Y_{0}$ and $C_{0}$ \\
$43-48$ & Achieves the polarity of the sum of $X_{1}, Y_{1}$ and $C_{1}$ \\
$49-50$ & Achieves the polarity of the carry of $X_{1}, Y_{1}$ and $C_{1}$ \\
$51-52$ & Achieves the polarity of the sum of $X_{2}, Y_{2}$ and $C_{2}$ \\
53 & Achieves the polarity of the carry of $X_{2}, Y_{2}$ and $C_{2}$ \\
\hline
\end{tabular}

ures 4 and 5 fulfil the terms to confirm that the proposed outlines are perpetual. Let a 2-dot 1-electron cell be of dimension $m \mathrm{~nm}$ and width $n$ nm. Figure 5 illustrates that it involves 300 cells. The operational extent enclosed is $300 \mathrm{~nm}^{2}$. Thus, the figure of QCA cells required is 300 , area covered is $16.272 \mathrm{~nm}^{2}$, and the number of majority vote is 12 .

\section{DERIVATION OF INNER ENERGY OF ELECTRON WITH DEPLETED POWER STUDY}

From physical properties, a 2-dot 1-electron cell with 1 electron is half of a 4-dot 2-electron equivalent, in which each cell embraces double electrons. As per the de Broglie's premise [13], an electron can be measured as a flow of electromagnetic waves instead as a super placed state of waves with separate wave dimensions. Scientifically, the Fourier depiction of super placed wave is

$$
\psi(f)=\frac{1}{\sqrt{2 \pi}} \int_{-\infty}^{+\infty} \varphi(k) e^{i k f} d k,
$$

where $\psi(f)$ is the packet of particles shifting along $f$ direction, $\varphi(k)$ is the amplitude of the packet, $k=2 \pi / \lambda$ is the proliferation 'rate' of an electron, $\lambda$ is the wavelength.

The packet $\psi(f)$ moves to achieve the minimal value at $x / 2$. From Equation (6), it is seen that the charge of $\psi(f)$ is proportionate to $\varphi(k)$ multiplied by various assessments of $e^{i k f}$. Hence, $\psi(f)$ emulates the performance of a cosine wave allowing its negative point at $x / 2$. Moreover, this specific performance can be realized in case of $\varphi(k)$. This property is called as Born's probabilistic interpretation [14]. In quantum mechanics, the most regular practice is to estimate the process energy 
as the amount of the dynamic energy and the system latent energy. Therefore, the overall process energy is signified here using $P$ as

$$
P=K+T,
$$

where $K$ denotes the kinetic energy, $T$ denotes the latent energy of the 2-dot QCA structure.

The impetus operator $\hat{\mathbf{P}}$ in the point representation $\mathbf{r}$ is present in Eq. (8), as obtained in [15]:

$$
\langle\mathbf{r}|\widehat{\mathbf{P}}| \psi\rangle=-i \hbar \nabla\langle\mathbf{r} \mid \psi\rangle,
$$

where $\langle\ldots\rangle$ is the Dirac's representation for defining quantum positions in quantum mechanics, $\hbar$ represents the condensed Planck's constant, $\nabla$ is the slope operator, and $i$ is $\sqrt{-1}$. Therefore, $\widehat{\mathbf{P}}$ in position depiction can be specified by

$$
\widehat{\mathbf{P}}=-i \hbar \nabla,
$$

where the Cartesian constituent of $\nabla$ in one-dimensional plot is $\partial / \partial x$. The kinetic energy is $K=-\left(2 m_{e}\right)^{-1} \widehat{\mathbf{P}}^{2}$, where $m_{e}$ clarifies the figure of an electron. Thus, the Hamiltonian operator can be presented as

$$
\widehat{H}=-\frac{\widehat{\mathbf{P}}^{2}}{2 m_{e}}+\widehat{C}(\mathbf{r})=-\frac{\hbar^{2}}{2 m_{e}} \nabla^{2}+\widehat{C}(\mathbf{r}) ;
$$

$\widehat{C}(\mathbf{r})$ is the Coulomb latent energy between two electrons in any two 2dot cells $m$ and $n$, each of which comprises charge $e$. Hence, $\widehat{C}(\mathbf{r})$ can be acquired as

$$
\widehat{C}(\mathbf{r})=\frac{\left|e^{2}\right|}{4 \pi \varepsilon_{o} \varepsilon_{r} r},
$$

where $\varepsilon_{o}$ is the open space permittivity, and $\varepsilon_{r}$ is the permittivity of the 2-dot 1-electron cell. Thus, the conceivable energy of an electron owing to the impact of all its neighbours is

$$
\widehat{C}(\mathbf{r})=\sum_{i} e \varphi\left(r_{i}\right)=\frac{1}{4 \pi \varepsilon_{o} \varepsilon_{r}} \sum_{i(\neq j)=1}^{2} \sum_{j=1}^{2} \frac{e_{i}^{m} e_{j}^{n}}{\left|r_{i}-r_{j}\right|} .
$$

Hence for a single cell, the conceivable energy is

$$
E_{P}=\frac{1}{N} \widehat{C}(\mathbf{r})=\frac{1}{N} \sum_{m=1}^{N} \sum_{n=1}^{N-1} \frac{1}{4 \pi \varepsilon_{o} \varepsilon_{r}} \sum_{i(\neq j)=1}^{2} \sum_{j=1}^{2} \frac{e_{i}^{m} e_{j}^{n}}{\left|r_{i}-r_{j}\right|} .
$$


The complete energy of the system is

$$
E_{C}=-\frac{\hbar^{2}}{2} \sum_{j=1}^{N} \frac{\nabla_{j}^{2}}{m_{e j}} \psi(\mathbf{r})+\sum_{m=1}^{N} \sum_{n=1}^{N-1} \frac{1}{4 \pi \varepsilon_{o} \varepsilon_{r}} \sum_{i(\neq j)=1}^{2} \sum_{j=1}^{2} \frac{e_{i}^{m} e_{j}^{n}}{\left|r_{i}-r_{j}\right|} .
$$

The energy of the system obtained from Eq. (14) makes the electrons of the cells to shift throughout the channels of the particular cells.

In 2-dot QCA architecture, both inner and outer flows of power are faced by each 2-dot QCA cell. Let $E_{s}$ and $E_{p}$ be instant signal energy and typical power energy because of input signal $x_{i}(t)$ where power estimations are systematized over the intermission $|t|<T$, where $T$ is half of the time interval. Then, the instant signal energy $E_{s}$ can be signified as

$$
E_{s}=\lim _{T \rightarrow \infty} \int_{-T}^{+T}\left|x_{i}(t)\right|^{2} d t .
$$

The typical power energy $E_{p}$ can be estimated as

$$
E_{p}=\lim _{T \rightarrow \infty} \frac{1}{2 T} \int_{-T}^{+T}\left|x_{i}(t)\right|^{2} d t .
$$

The combined power and energy because of all the input signals related to the input cells can be stated as

$$
\begin{aligned}
& E_{e n 1}=\sum_{i=1}^{n} E_{p}, \\
& E_{e n 2}=\sum_{i=1}^{n} E_{s},
\end{aligned}
$$

where $E_{e n 1}$ and $E_{e n 2}$ are the power and signal energy, correspondingly, provided from the conditions to the 2-dot 1-electron QCA architecture, $n$ is the number of input lines into the circuit. These energy and power have to proliferate throughout the architecture, and this is achieved through the link effect of 2-dot 1-electron QCA.

\section{ENERGY AND POWER DEPLETION IN THE OUTLINED LAYOUT}

For energy and power calculation, several factors are taken from [16]: $E_{m}$, the minimal energy to be provided to the design holding $N$ cells; $E_{c l k}$, the energy to be provided by the clock to the layout; $E_{d e p}$, energy depletion from the layout with $N$ cells; $v_{2}$, frequency of depleted energy; $\tau_{2}$, time to deplete into the situation to come to the lenient status; $v_{1}$, incident energy frequency; $\tau_{1}$, essential time to extend the quantum level $n$ from quantum level $n_{2}$ (here, $n=2$ and $n_{2}=2$ ); $\tau$ is the time needed by the cells in one clock region to switch from one to the suc- 
ceeding polarization; $t_{p}$, proliferation time throughout the architecture; $v_{2}-v_{1}$, the variance frequency. The parameters of ripple carry adder are presented in Table 3. Here, the number is presented by $n$, reduced Planck's constant is $\hbar$, electron mass is $m_{e}, N$ cells are applied to form the design, which goes across $k$ number of clock periods.

Table 4 presents a comparative analysis on ripple carry adder. The outlined design with 2-dot 1-electron has been assessed with the present design using 4-dot 2-electron cells considering total number of cells, covered area, energy depleted, and majority gates. From the analysis, it is comprehended that the number of QCA cells need for the 2-dot 1-electron layout are far less than that in case of 4-dot 2-electron counterparts [17, 18], and, consequently, the gates applied are less. Furthermore, the energy essential to handle the designs is far less in case of 2-dot 1-electron designs as the figure of electrons occupied are the same as the figure of cells while in case of 4-dot 2-electron designs as the figure of electrons occupied are simply the twice of figure of

TABLE 3. Various features and values of 2-dot 1-electron QCA ripple carry adder.

\begin{tabular}{cc}
\hline Features & Values \\
\hline$E_{m}=\frac{n^{2} \pi^{2} \hbar^{2} N}{m_{e} a^{2}}$ & $1.868 \cdot 10^{-17} \mathrm{~J}$ \\
$E_{d e p}=\frac{\pi^{2} \hbar^{2}}{m_{e} a^{2}}\left(n^{2}-1\right) N$ & $1.840 \cdot 10^{-17} \mathrm{~J}$ \\
$v_{1}=\frac{\pi \hbar}{m_{e} a^{2}}\left(n^{2}-n_{2}{ }^{2}\right) N$ & $5.112 \cdot 10^{16} \mathrm{~Hz}$ \\
$v_{2}=\frac{\pi \hbar}{m_{e} a^{2}}\left(n^{2}-1\right) N$ & $1.768 \cdot 10^{15} \mathrm{~Hz}$ \\
$v_{1}-v_{2}=\frac{\pi \hbar}{m_{e} a^{2}}\left(n_{2}{ }^{2}-1\right) N$ & $4.935 \cdot 10^{16} \mathrm{~Hz}$ \\
$\tau_{1}=\frac{1}{v_{1}}=\frac{m_{e} a^{2}}{\pi \hbar\left(n^{2}-n_{2}^{2}\right)} N$ & $1.956 \cdot 10^{-17} \mathrm{~s}$ \\
$\tau_{2}=\frac{1}{v_{2}}=\frac{m_{e} a^{2}}{\pi \hbar\left(n^{2}-1\right)} N$ & \\
$\tau=\tau_{1}+\tau_{2}$ & $5.656 \cdot 10^{-16} \mathrm{~s}$ \\
$t_{p}=\tau+(k-1) \tau_{2} N$ & $5.851 \cdot 10^{-16} \mathrm{~s}$ \\
\hline
\end{tabular}


TABLE 4. Assessment of existing 4-dot 2-electron QCA ripple carry adder with the proposed 2-dot 1-electron QCA.

\begin{tabular}{c|c|c|c}
\hline Parameters & Design in Ref. [17] & Design in Ref. [18] & Proposed \\
\hline $\begin{array}{c}\text { Cell number } \\
\text { Majority voter }\end{array}$ & 339 & 651 & 300 \\
used & 16 & 16 & 12 \\
Required energy & $\begin{array}{c}\text { Comparatively } \\
\text { higher because of } \\
678 \text { electrons }\end{array}$ & $\begin{array}{c}\text { Comparatively } \\
\text { higher because of } \\
1302 \text { electrons }\end{array}$ & $\begin{array}{c}\text { Comparatively } \\
\text { lower because of } \\
300 \text { electrons }\end{array}$ \\
\hline
\end{tabular}

cells occupied. The entailed energy is precisely proportional to the figure of cells involved [16].

\section{CONCLUSION}

In this study, a layout of a ripple carry adder with 2-dot 1-electron QCA is proposed based on 2-dot 1-electron full adder. Since no simulator is presented for 2-dot 1-electron QCA, validation is completed with potential energy estimations. It is reasonable that the logically adder and ripple carry adder with 2-dot 1-electron QCA are far more cost efficient with regard to extent and power dissipation than the uniform using 4-dot 2-electron QCA. Besides, the overall energy and power required by the design are also calculated.

\section{REFERENCES}

1. C. S. Lent and P. D. Tougaw, Proceedings of the IEEE, 85, No. 4: 541 (1997).

2. A. N. Bahar, M. S. Uddin, Md. A. A. Shafi, M. M. R. Bhuiyan, and K. Ahmed, Alexandria Engineering Journal (2017), http://dx.doi.org/10.1016/j.aej.2017.02.002.

3. Md. A. A. Shafi, A. N. Bahar, M. A. Habib, M. M. R. Bhuiyan, F. Ahmad, P. Z. Ahmad, and K. Ahmed, Ain Shams Engineering Journal (2017), https://doi.org/10.1016/j.asej.2017.05.010.

4. Md. A. A. Shafi and A. N. Bahar, Cogent Engineering, 4, No. 1: 1391060 (2017).

5. Md. A. A. Shafi, A. N. Bahar, F. Ahmad, and K. Ahmed, Cogent Engineering, 4, No. 1: 1349539 (2017).

6. L. R. H. Iv and S. C. Lee, IEEE Trans. Nanotechnol., 10: 996 (2011).

7. D. Mukhopadhyay, S. Dinda, and P. Dutta, Int. J. Comput. Appl., 25: 21 (2011).

8. P. Dutta and D. Mukhopadhyay, Adv. Sci. Lett., 5: 163 (2012).

9. Md. A. A. Shafi and A. N. Bahar, Journal of Computational and Theoretical Nanoscience, 14: 2416 (2017).

10. Md. A. A. Shafi, A. N. Bahar, F. Ahmad, M. M. R. Bhuiyan, and K. Ahmed, Data in Brief, 11: 593 (2017). 
11. Md. A. A. Shafi and A. N. Bahar, Cogent Engineering, 3, No. 1: 1237864 (2016).

12. Md. A. A. Shafi and A. N. Bahar, Proc. of the 5th International Conference on Informatics, Electronics \& Vision (ICIEV) (Dhaka, Bangladesh: 2016), p. 620.

13. K. Blum, Density Matrix Theory and Applications. Springer Series on Atomic, Optical and Plasma Physics (Springer: 2012).

14. M. Born, Born's Nobel Lecture on the Statistical Interpretation of Quantum Mechanics (Amsterdam: Elsevier Publishing: 1954).

15. N. Zettili, Quantum Mechanics Concept and Application (West Sussex, United Kingdom: Wiley: 2009).

16. D. Mukhopadhyay and P. Dutta, Microelectron. J., 46, No. 6: 519 (2015).

17. V. Pudi and K. Sridharan, IEEE Transactions on Nanotechnology, 11, No. 1: 105 (2012).

18. H. Cho and E. E. Swartzlander, IEEE Trans. Nanotechnol., 6, No. 3: 374 (2007). 